\title{
Faktor - faktor yang yang mempengaruhi produksi kerajinan batik di Kota Jambi
}

\author{
Andrian Dwi Ramadan*; Rahma Nurjanah; Erni Achmad
}

Prodi Ekonomi Pembangunan Fak. Ekonomi dan Bisnis Universitas Jambi

E-mail korespondensi: andriandwiramadani@gmail.com

\begin{abstract}
This study aims to determine the development of labor, investment and business units in the production of the batik industry in Jambi City. This research uses quantitative data collection methods. The data used in this study is secondary data, secondary data used is a combination of periodic series (time series). In this study, it is assumed that labor, investment, and business units have a positive and significant effect on Jambi batik production in Jambi City. The data used in this study are data on labor, investment, business units, and batik production in Jambi City from 2006-2017. The data is processed using SPSS with multiple linear regression analysis methods.
\end{abstract}

Keywords: Labor, Investment, Business units, Production.

\begin{abstract}
Abstrak
Penelitian ini bertujuan untuk mengetahui perkembangan tenaga kerja, investasi dan unit usaha terhadap produksi industri batik di Kota Jambi. Penelitian ini menggunakan metode pengumpulan data kuantitatif . Data yang dipergunakan dalam penelitian ini adalah data sekunder, data sekunder yang digunakan adalah penggabungan dari deret berkala (time series). Penelitian ini diduga tenaga kerja, investasi dan unit usaha berpengaruh positif dan signifikan terhadap produksi batik Jambi di Kota Jambi. Data yang digunakan dalam penelitian ini adalah data tenaga kerja, investasi, unit usaha dan produksi batik di Kota Jambi tahun 2006-2017. Data tersebut diolah menggunakan SPSS dengan metode analisis regresi linear berganda.
\end{abstract}

Kata kunci :Tenaga kerja, Investasi, Unit usaha, Produksi.

\section{PENDAHULUAN}

Industri batik di Indonesia umumnya merupakan Industri Mikro, Kecil dan Menengah (IMKM) atau Usaha Mikro Kecil dan Menengah (UMKM) yang menjadi mata pencarian sebagian masyaratkat dalam pembangunan ekonomi di Indonesia UMKM selalu digambarkan sebagai sektor yang mempunyai peran yang penting, karena sebagian besar jumlah penduduknya berpendidikan rendah dan hidup dalam kegiatan usaha kecil batik sektor tradisional maupun modern. Menurut UU No. 20 Tahun 2008 pasal 3 UMKM bertujuan untuk menumbuhkan dan menggambarkan usahanya dalam rangka membangun perekonomian nasional berdasarkan demograsi ekonomi yang berkaitan. Di Indonesia di buat diberbagai daerah terutama pada Pulau Jawa. Jawa Tengah merupakan pusat kegiatan pembatikan, di bandingkan pembatikan daerah lain, batik daerah Jawa Tengah lebih halus pembatikannya. Setiap daerah pembatikannya mempuyai keunikan dan ciri khas masing-masing, baik dalam rangka hias maupun tata warnanya. Namun demikian dapat dilihat adanya persaman maupun perbedaan antar batik berbagai daerah 
tersebut. Bangsa Indonesia sebagai suatu bagsa yang bersatu, walupun terdiri dari berbagai suku bangsa dengan adat yang berbeda, ternyata memiliki selera dan pola citra yang hampir sama. Tentu saja kalau ada perbedaan dalam gaya dan selerah, itu sebabkan oleh letak geografi daerah pembuatan batik yang bersangkutan, sifat dan tata penghidupan daerah yang bersangkutan, kepercayaan dan adat istiadat yang ada di daerah yang bersangkutan, keadaan alam sekitarnya dan ada kontak atau hubungan dengan daerah pembatik kain (Djoemen,1990). Pembangunan industri menciptakan pasar bagi industri lain dan makin banyak industri yang di bangun, makin luas pasar dan memungkinkannya untuk menggunakan modal dengan lebih efisien dan intensif. Dengan demikian, pembangunan seimbang akan menjadi peransang untuk mengadakan lebih banyak penanaman modal. Pengembangan ekonomi di era modern ini memang peranan industri sangat penting, dan sektor industri adalah sektor unggul dan justru dapat membawa dampak pada pertumbuhan ekonomi yang lebih baik (Sukirno, 2006). Pada era globalisasi kegiatan ekonomi dan perdagangan negara-negara didunia menjadi suatu kekuatan pasar yang semakin terintegrasi tanpa rintangan batas teritorial negara. Setiap negara di tuntut memiliki daya saing tinggi agar mampu bersaing dengan negara lain. Daya saing merupakan hal yang sangat penting untuk dimiliki oleh setiap negara tingginya daya saing suatu negara akan berimplikasi pada peningkatan pertumbuhan ekonomi dan kesejahteraan. Untuk meningkatkan daya saing global, beberapa negara dalam suatu kawasan biasanya membentuk integrasi ekonomi. Kedekatan geografis dan historis serta hubungan ekonomi antar negara disuatu kawasan tersebut seringkali menjadi pendorong utama pembentukkan integrasi ekonomi.

Menurut Badan Pusat satistik (2018). Jumlah usaha Mikro kecil dan menengah (UMKM) di Provinsi Jambi terus mengalami peningkatan dari tahun ke tahun. Tahun 2017 suda mencapai 100.898 UMKM. Rinciannya, 87.669 usaha mikro, 12.674 usaha kecil dan 555 usaha menengah. Jika di totalkan jumlah UMKM di Provinsi Jambi mengalami kenaikan 2,8\% bila di bandingkan dengan tahun sebelumnya. Tahun 2016 total UMKM di Provinsi Jambi mencapai 98.169 usaha kecil dan 1.252 usaha menengah. UMKM adalah mata pencaharian yang paling banyak di Jambi karna bersentuhan langsung dengan pekerjaan masyarakat yaitu petani.

Tabel 1. Data unit usaha, produksi, investasi dan tenaga kerja industri batik Kota Jambi tahun 20013-2017

\begin{tabular}{|c|c|c|c|c|c|}
\hline \multirow[b]{2}{*}{ Tahun } & \multirow{2}{*}{$\begin{array}{c}\text { Unit } \\
\text { usaha } \\
\text { (unit) }\end{array}$} & \multicolumn{2}{|c|}{ Produksi } & \multirow{2}{*}{$\begin{array}{c}\text { Investasi } \\
\text { (juta) }\end{array}$} & \multirow{2}{*}{$\begin{array}{l}\text { Tenaga kerja } \\
\quad \text { (orang) }\end{array}$} \\
\hline & & $\begin{array}{c}\text { Satuan } \\
\text { unit }\end{array}$ & Volume & & \\
\hline 2013 & 56 & Potong & 44.933 & 643.105 & 283 \\
\hline 2014 & 58 & Potong & 45.348 & 604.300 & 305 \\
\hline 2015 & 61 & Potong & 53.216 & 710.865 & 340 \\
\hline 2016 & 46 & Potong & 49.823 & 508.439 & 289 \\
\hline 2017 & 34 & Potong & 45.348 & 406.302 & 265 \\
\hline
\end{tabular}

Sumber: Dinas perindagkop Kota Jambi tahun 2000-2017(diolah)

Pada Tabel 1. produksi batik di Kota Jambi dihitung dengan satuan potong. Pada tahun 2013 produksi batik di Kota Jambi 44.933 potong, tenaga kerja 283 orang, investasi 643.105 juta dan unit usaha 56 unit. Dari tahun 2013-2017 produksi batik di Kota Jambi yang terkecil terdapat pada tahun 2013, disebabkan karena penggunaan teknologi kurang, fasilitas pendukung yang masih minimum, kontinuitas bahan baku yang terbatas, 
kemampuan usaha menjual batik pada pasar lokal yang masih rendah, kurangnya interaksi yang dilakukan antar pengusaha atau pengrajin dan kompetensi tenaga kerja yang rendah. Produksi batik di Kota Jambi yang terbesar dari tahun 2013- 2017 terdapat pada tahun 2015, disebabkan karena peningkatan sumber daya manusia, fasilitas pendukung yang mulai memadai, kontinuitas bahan baku dan peningkatan penjualan batik pada pasar lokal. Teori produksi merupakan analisis mengenai bagaimana seharusnya seorang pengusaha atau produsen, dalam teknologi tertentu memilih dan mengkombinasikan berbagai macam faktor produksi untuk menghasilkan sejumlah produksi tertentu, seefisien mungkin (Suherman, 2002). Faktor-faktor produksi yang digunakan dalam proses produksi sangatlah penting, agar proses produksi yang dihasilkan dapat efisien dan hasil produksi dapat menjadi optimal. Teori produksi yang menggambarkan tentang hubungan antara tingkat produksi suatu barang dengan dengan jumlah tenaga kerja yang digunakan untuk menghasilkan berbagai tingkat produksi barang tersebut. Produksi merupkan aktivitas ekonomi dengam memanfaatkan beberapa bahan baku.

Menurut Hirschman, pertumbuhan yang cepat dari satu atau beberapa industri mendorong perluasan industri-industrilainnya yang terkait dengan sektor industri yang tumbuh lebih dulu. Dalam sektor produksi mekanisme pendorong pembangunan (indecement mechanisme) yang tercipta sebagai akibat dari adanya hubungan antara berbagai industri dalam menyediakan barang-barang yang digunakan sebagai bahan mentah bagi industri lainnya (Arsyad, 2010).

Pengertian industri memiliki beberapa pandangan dan pendekatan yang berbedabeda dari berbagai pihak. Menurut Departemen Perindustrian (2007), industri adalah suatu kegiatan ekonomi yang mengolah bahan mentah, bahan baku, barang setengah jadi, atau barang jadi menjadi barang dengan nilai yang lebih tinggi untuk penggunaanya, termasuk kegiatan rancang bangun dan perekayasaan industri. Industri merupakan sebagai kelompok perusahaan yang memproduksi barang dan jasa dengan elastisitas silang yang positif dan tinggi (Kuncoro, 2007). Sedangkan, menurut Badan Pusat Statistik (2008), industri mempunyai dua pengertian, pengertian secara luas dan pengertian secara sempit.

Faktor-faktor produksi yang digunakan dalam proses produksi sangatlah penting, agar proses produksi yang dihasilkan dapat efisien dan hasil produksi dapat menjadi optimal. Teori produksi yang menggambarkan tentang hubungan antara tingkat produksi suatu barang dengan dengan jumlah tenaga kerja yang digunakan untuk menghasilkan berbagai tingkat produksi barang tersebut. Produksi merupkan aktivitas ekonomi dengam memanfaatkan beberapa bahan baku.

Produksi adalah transformasi masukan (input) atau sumber daya (resources) menjadi keluaran (output) barang dan jasa yang mempunyai nilai tambah. Keluaran bisa saja merupkan produk akhir atau setengah jadi. Masukan adalah sumber daya yang digunakan dalam produksi barang dan jasa. Masukan dapat berupa masukan tetap dan masukan berubah. Masukan tetap adalah masukan yang tidak berubah jumlahnya dalam proses produksi kendati keluaran berubah (bertambah atau berkurang). Masukan berubah adalah masukan yang berubah sejalan dengan perubahan keluaran (Tambunan, 2002).

Tenaga kerja merupakan komponen produksi selain faktor produksi tanah dan modal yang mempunyai peran penting dalam mendukung kegiatan membuatan suatu produk barang atau jasa. Pertambahan permintaan barang dan jasa di masyarakat akan mengakibatkan peningkatan permintaan tenaga kerja. Permintaan ini disebut derived demand, karena berubahnya tenaga kerja yang diminta sebagai input ditentukan oleh perubahan permintaan outputnya (Simanjuntak, 2001). 
Tenaga kerja adalah penduduk dalam usia bekerja atau jumlah seluruh penduduk dalam suatu negara dalam memproduksi barang atau jasa. Tenaga kerja yang masuk dalam usia kerja yaitu antara 15-64 tahun (Suparmoko, 2013). Tiga golongan yang disebut pencari kerja, bersekolah dan mengurus rumah tangga walaupun tidak sedang bekerja mereka dianggap secara fisik maupun sewaktu-waktu dapat ikut bekerja. Secara praktis pengertian tenaga kerja dan bukan tenaga kerja di bedakan hanya oleh batas umur. Dimana tiap-tiap negara memberi batasan umur yang berbeda (Mulyani, 2010).

Menurut Badan Pusat Statistik, tenaga kerja adalah penduduk usia 15 tahun keatas yang sedang bekerja, yang memiliki pekerjaan namun sementara tidak bekerja, seseorang yang tidak memiliki pekerjaan dan sedang mencari pekerjaan dikategorikan bekerja. Tenaga kerja dalam masyarakat dikategorikan faktor potensial untuk pembangunan ekonomi masyarakat secara keseluruhan. Jumlah penduduk Indonesia yang cukup besar akan menentukan perceptan laju pertumbuhan ekonomi, baik melalui pengukuran produktivitas maupun melaluki pengukuran pendapatan perkapita. Selain itu kesempatan kerja merupakan sumberdaya untuk menjalankan proses produksi dan juga distribusi barang dan jasa (Sumarsono, 2003).

Investasi merupakan biaya pengeluaran untuk penanaman modal atau pengeluaran perusahaan untuk membeli barang-barang, modal dan perlengkapan-perlengkapan produksi untuk menambah kemampuan memproduksi barang dan jasa yang tersedia dalam perekonomian. Pertambahan barang modal ini memungkinkan perekonomian untuk memproduksi lebih banyak barang dan jasa dimasa yang akan datang. Ada kalanya penanaman modal digunakan untuk menggantikan barang-barang modal yang lama dan perlu di depresiasikan (Sukirno, 2010).

Kegiatan investasi memungkinkan suatu masyarakat terus menerus meningkatkan kegiatan ekonomi dan kesempatan kerja, meningkatkan pendapatan nasional dan meningkatkan taraf kemakmuran masyarakat. peranan ini bersumber dari tiga fungsi penting kegiatan investasi dalam perekonomian. Pertama, investasi merupakan salah satu komponen dari pengeluaran agregat, sehingga kenaikan investasi akan meningkatkan permintaan agregat dan pendapatan nasional. Kedua, pertambahan barang modal sebagai akibat investasi akan menambah kapasitas memproduksi di masa depan dan perkembangan ini akan menstimulir pertambahan produksi nasional serta kesempatan kerja. Ketiga, investasi selalu diikuti selalu diikuti oleh perkembangan teknologi, perkembangan ini akan memberi sumbangan penting terhadap peningkatan produktivtas dan pendapatan perkapita masyarakat.

Menurut Keynes, bunga adalah semata-mata gejala moneter, bunga adalah pembayaran untuk menggunakan uang. Berdasarkan atas pendapatan demikian mengapa Keynes yakinbahwa akan pengaruh uang terhadap sistem ekonomi seluruhannya. Tingkat bunga memiliki fungsi alokasi dalam perekonomian, khususnya dalam penggunaan uang dan modal. Tingkat bunga ditentukan oleh penawaran dan permintaan uang. Tingkat bunga akanmempengaruhi kegiatan ekonomi. Perubahan tingkat bunga selanjutnya akan mempengaruhi investasai (Mankiw, 2003).

Dengan adanya peningkatan investasi pada suatu industri, juga akan meningkat penyerapan tenaga kerja. Hal ini dikarenakan oleh peningkatan investasi maka akan meningkatkan jumlah perusahaan yang ada pada industri tersebut. Peningkatan jumlah perusahaan maka akan maningkatkan jumlah output yang akan dihasilkan sehingga lapangan pekerjaan meningkat penyerapan tenaga kerja. Sedangkn menurut Karib (2012), jumlah unit usaha erat dengan penyerapan tenaga kerja pada sektor industri dilihat dari meningkatnya jumlah usaha. 
Usaha adalah suatu kegiatan yang dilakukan dengan tujuan memperoleh hasil berupa keuntungan, upah atau laba usaha. Usaha merupakan kegiatan dengan mengerakkan tenaga kerja, pikiran atau badan untuk mencapai suatu maksud pekerjaan untuk memcapai sesuatu yang di inginkan.

\section{METODE}

Data yang dipergunakan dalam penelitian ini adalah data sekunder. Data sekunder adalah data yang mengacu pada informasi yang dikumpulkan dari sumber yang telah ada, berupa catatan atau dokumentasi perusahaan, publiksi pemerintah, analisis industri oleh media, situs web, internet dan seterusnya.

Dalam penelitian ini menggunakan analisis deskriptif dengan pendekatan kuantitatif bertujuan untuk menjelaskan dan menggambarkan variabel-variabel yang ada dalam penelitian, kemudian dipaparkan oleh penulis dalam bentuk angka-angka.

Dengan formula sebagai berikut :

$$
X_{o}=\frac{X_{t-X_{t-1}}}{X_{t-1}} X 100 \%
$$

Keterangan :

$X o=$ Perkembangan variabel $\mathrm{X}$

$X_{t} \quad=$ Tingkat Variabel $\mathrm{X}$ di tahun $\mathrm{t}$

$X_{t-1} \quad=$ Tingkat variabel $\mathrm{X}$ tahun sebelumnya

Metode analisis kuantitatif merupakan suatu metode yang digunakan untuk melihat secara empiris sejauh mana pengaruh variabel bebas / independen terhadap variabel terkait terpilih.analisis ini digunakan untuk menguji hipotesis yang bersifat kuantitatif atau statistik (Sugiyono, 2014).

Untuk menjawab tujuan kedua digunakan rumus sebagai berikut :

$$
\log P R O=\beta O+\beta_{1} \operatorname{LogTK}+\beta_{2} \operatorname{LogINV}+\beta_{3} \log U U+e
$$

Keterangan :

PRO : Produksi industri batik

Bo $\quad$ : Konstanta persamaan regresi

$\beta_{1} \beta_{2} \beta_{3}$ : Koefisien masing-masing variabel

TK : Tenaga kerja industri batik

INV : Investasi industri batik

UU : Unit usaha industri batik

e : Standar eror

\section{HASIL DAN PEMBAHASAN}

\section{Perkembangan investasi batik di Kota Jambi}

Investasi batik di Kota Jambi cendrung mengalami fluktuasi selama tahun 2000 2017. Rata-rata total perkembangan investasi batik di Kota Jambi sebesar 30,88\%. Perkembangan tertinggi terjadi pada tahun 2006 dengan persentase sebesar 324,36\% dari tahun sebelumnya. Sedangkan perkembangan terendah terjadi pada tahun 2008 dengan 
persentase sebesar $-67,36 \%$ dari tahun sebelumnya. Ada dua faktor utama yang mempengaruhi tinggi rendahnya tingkat investasi, yaitu suku bunga dan tingkat pengembalian yang diharapkan. Tingkat suku bunga pinjaman adalah biaya investasi yang menjadi perhatian bagi para investor sebelum menanamkan modal.

\section{Perkembangan tenaga kerja batik di Kota Jambi}

Tenaga kerja batik di Kota Jambi cendrung mengalami fluktuasi selama periode 2000 sampai tahun 2017. Rata-rata total perkembangan tenaga kerja batik di Kota Jambi sebesar 26,60\%. Perkembangan tertinggi terjadi pada tahun 2001 dengan persentase sebesar 160,87\% dari tahun sebelumnya. Sedangkan perkembangan terendah terjadi pada tahun 2008 dengan persentase sebesar $-44,90 \%$ dari tahun sebelumnya.

Pada tahun 2010-2017 jumlah tenaga kerja mengalami fluktuasi, pada tahun 2010 jumlah tenaga kerja sebanyak 392 orang atau perkembangannya turun dari tahun sebelumnya sebesar $-24,61 \%$. Tahun 2017 jumlah tenaga kerja menjadi 265 orang atau perkembangannya menurun dari tahun sebelumnya sebesar-8,30\%. Salah satu penyebab rendahnya jumlah tenaga kerja batik di Kota Jambi adalah kurangnya pemahaman sumber daya manusia tentang batik dan masyarakat sudah mulai suka dengan budaya luar sehingga semakin sedikit peminat batik.

\section{Perkembangan unit usaha batik di Kota Jambi}

Perkembangan unit usaha batik di Kota Jambi cendrung mengalami fluktuasi selama periode 2000 sampai tahun 2017. Rata-rata total perkembangan unit usaha batik di Kota Jambi sebesar 11,6\%. Perkembangan tertinggi terjadi pada tahun 2005 dengan persentase sebesar $183,33 \%$ dari tahun sebelumnya. Sedangkan perkembangan terendah terjadi pada tahun 2012 dengan persentase sebesar $-27,91 \%$ dari tahun sebelumnya.

Tabel 2. Hasil regresi

\begin{tabular}{lrrrr}
\hline \multicolumn{1}{c}{ Variable } & Coefficient & Std. Error & t-Statistic & Prob. \\
\hline C & 12.44685 & 1.279337 & 9.729137 & 0.0000 \\
LOG(TK) & 0.703085 & 0.155625 & 4.517823 & 0.0005 \\
LOG(INV) & -0.319692 & 0.138609 & -2.306430 & 0.0369 \\
LOG(UU) & -0.329677 & 0.173784 & -1.897057 & 0.0786 \\
\hline R-squared & 0.608453 & Mean dependent var & 11.01829 \\
Adjusted R-squared & 0.524551 & S.D. dependent var & 0.341667 \\
S.E. of regression & 0.235589 & Akaike info criterion & 0.139673 \\
Sum squared resid & 0.777030 & Schwarz criterion & 0.337533 \\
Log likelihood & 2.742942 & Hannan-Quinn criter. & 0.166955 \\
F-statistic & 7.251879 & Durbin-Watson stat & 1.612947 \\
Prob(F-statistic) & 0.003592 & & \\
\hline
\end{tabular}

Sumber : Data diolah, 2020

Berdasarkan hasil olahan data diperoleh model persamaan regresi linier berganda sebagai berikut :

LOG $($ PRO $)=\beta 0+\beta 1 L O G($ TK) $+\beta 2 L O G(I N V)+\beta 3 L O G(U U)+e$

12.44685 + 0.703085LOG(TK)- 0.319692LOG(INV) - 0.329677LOG(UU) 
(0.0000)

(0.0005)

(0.0369)

(0.0786)

\section{Uji statistik}

\section{Uji F statistik}

Uji F digunakan untuk mengetahui apakah variabel tenaga kerja, investasi, dan unit usaha berpengaruh terhadap roduksi batik. Dari hasil regresi dengan menggunakan Eviews 10 diperoleh nilai $\mathrm{F}$ hitung sebesar (0.003592) dengan membandingkan antara $\mathrm{F}$ hitung dengan $\mathrm{F}$ tabel dimana $\alpha=5 \%$ dengan nilai $\mathrm{F}$ tabel sebesar $(0,5 \%)$. Dari nilai tersebut dimana $\mathrm{F}$ hitunglebih kecil dari $\mathrm{F}$ tabel $(0.003592)<0.05 \%)$, artinya adalah $\mathrm{H}_{0}$ ditolak, maka dapat disimpulkan bahwa Tenaga kerja, investasi, dan unit usaha secara bersama-sama berpengaruh secara signifikan terhadap produksi batik.

\section{Uji t statistik}

Untuk mengetahui pengaruh variabel independen terhadap variabel dependen secara individu maka digunakan uji t. untuk menguji hipotesis maka dilakukan uji $t$ dengan tingkat signifikan 5\%, dari hasil regresi diketahui t hitung masing-masing variabel adalaha sebagai berikut:

Tabel 3. Koefisien variabel bebas

\begin{tabular}{crrrr}
\hline Variable & Coefficient & Std. Error & t-Statistic & Prob. \\
\hline C & 12.44685 & 1.279337 & 9.729137 & 0.0000 \\
LOG(TK) & 0.703085 & 0.155625 & 4.517823 & 0.0005 \\
LOG(INV) & -0.319692 & 0.138609 & -2.306430 & 0.0369 \\
LOG(UU) & -0.329677 & 0.173784 & -1.897057 & 0.0786 \\
\hline
\end{tabular}

Sumber :Data diolah 2020

Variabel Tenaga Kerja dari hasil regresi diperoleh nilai thitung sebesar 4.51 dengan tingkat probabilitas variabel tenaga kerja sebesar 0.0005 atau lebih kecil dari nilai $\alpha=5 \%$ $(0.0005<0.05)$, maka H1 diterima dan $\mathrm{H} 0$ ditolak, yang mengindikasikan bahwa variabel tenaga kerja berpengaruh positif dan signifikan terhadap produksi.

Variabel Investasi Dari hasil regresi diperoleh nilai t hitung sebesar 2.30 dengan tingkat probabilitas variabel investasi sebesar 0.0369 atau lebih kecil dari $\alpha=(0.0109<$ 0.05 ), maka H1 diterima dan $\mathrm{H} 0$ ditolak, yang mengindikasikan bahwa variabel investasi berpengaruh negatif dan signifikan terhadap produksi.

Variabel Unit Usaha dari hasil regresi diperoleh nilai t hitung sebesar 1.89 dengan tingkat probabilitas variabel Unit Usaha sebesar 0.0786 atau lebih besar dari $\alpha=5 \%$ $(0.0109<0.05)$, maka H1 ditolak dan H0 diterima, yang mengindikasikan bahwa variabel unit usaha berpengaruh negatif dan tidak signifikan terhadap produksi.

\section{Koefisien determinan $\left(\mathbf{R}^{2}\right)$}

Berdasarkan pengujian model diperoleh nilai koefisien determinan $\mathrm{R}^{2}$ sebesar 0.608453 artinya bahwa $60 \%$ kontribusi variabel indevenden terhadap variabel dependen, sedangkan sisanya $40 \%$ lagi disebabkan oleh variabel lain yang tidak dimasukkan kedalam penelitian ini.

\section{Uji asumsi klasik}

\section{Uji normalitas}

Uji ini dilakukan untuk melihat apakah model regresi variabel penganggu atau residulnya memiliki distribusi normal. Uji ini dilakukan dengan membandingkan nilai 
Jarque-Berra dengan nilai tabel chi-square $\left(\mathrm{X}^{2}\right)$. Dari gambar diatas diperoleh nilai prob. $(0.453890)>$ nilai tabel chi-square $\left(\mathrm{X}^{2}\right)$ sebesar $(0,05)$ artinya model lolos dari ketidak normalan distribusi residual.

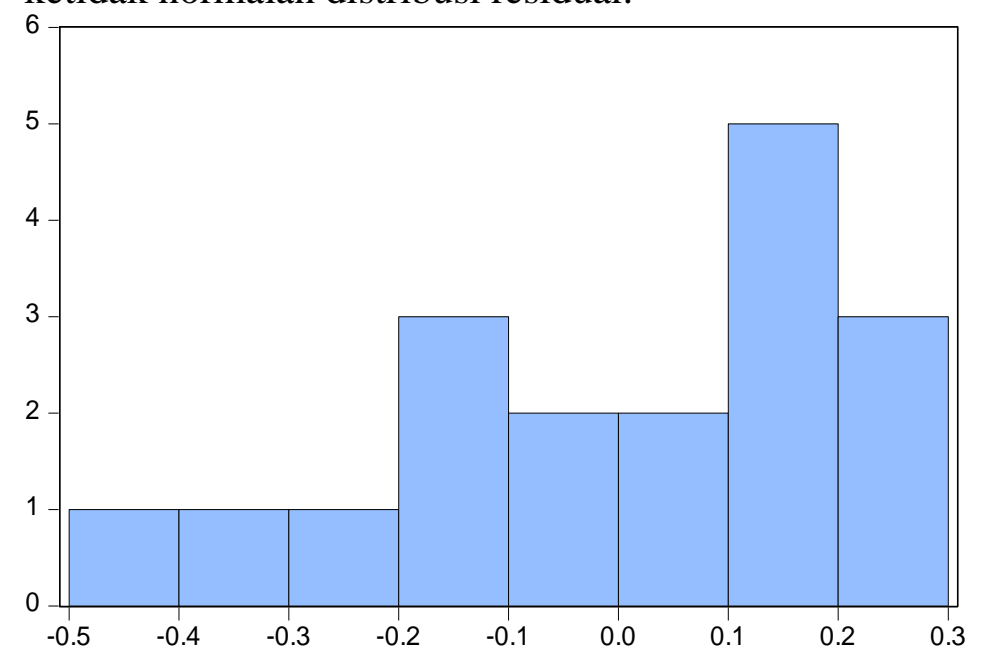

\begin{tabular}{|lr} 
Series: Residuals \\
Sample 2000 2017 \\
Observations & 18 \\
& \\
Mean & $-2.87 \mathrm{e}-15$ \\
Median & 0.068727 \\
Maximum & 0.281474 \\
Minimum & -0.482826 \\
Std. Dev. & 0.213793 \\
Skewness & -0.708353 \\
Kurtosis & 2.684811 \\
& \\
Jarque-Bera & 1.579801 \\
Probability & 0.453890 \\
\hline
\end{tabular}

Gambar 1 Uji normalitas

\section{Uji multikolinieritas}

Uji ini dimaksudkan untuk melihat adanya korelasi yang pasti diantara variabel bebas, dimana dalam kondisi ini variabel-variabel bebas tidak ortogonal. Variabelvariabel yang bersifat ortogonal adalah variabel bebas yang nilai korelasi diantara sesamanya sama dengan nol.

Tabel 4. Uji multikolinieritas

\begin{tabular}{|c|c|c|c|}
\hline \multirow[b]{3}{*}{ Variable } & \multicolumn{2}{|c|}{ Coefficien Uncentere } & \multirow[t]{2}{*}{ Centered } \\
\hline & & d & \\
\hline & Variance & VIF & VIF \\
\hline $\bar{C}$ & 1.636704 & 530.8027 & NA \\
\hline LOG(TK) & 0.024219 & 230.5596 & 5.416825 \\
\hline LOG(INV) & 0.019212 & 991.2338 & 4.493298 \\
\hline LOG(UU) & 0.030201 & 129.9806 & 6.685087 \\
\hline
\end{tabular}

Sumber: Data yang diolah, 2020

Berdasarkan hasil olahan data nilai Centered VIF kurang dari 10, maka dapat disimpulkan bahwa tidak terjadi multikolinieritas dan hal tersebut menunjukkan adanya hubungan linier yang sempurna diantara beberapa atau semua variabel independen dari model regresi.

\section{Autokorelasi}

Uji ini digunakan untuk mengetahui ada atau tidaknya autokorelasi. Autokorelasi merupakan suatu keadaan dimana variabel independen pada periode tertentu berkorelasi dengan variabel independen pada periode lainnya, dengan kata lain variabel independen tidak random atau korelasi diantara variabel yang berurutan dari data time series. Uji yang digunakan adalah Breusch-Godfrey Serial Correlalation LM Test. Berikut ini hasil uji autokorelasi:

Tabel 5. Autokorelasi

Breusch-Godfrey Serial Correlation LM Test:

\begin{tabular}{llll}
\hline F-statistic & 0.127972 & Prob. F(2,12) & 0.8811 \\
Obs*R-squared & 0.375900 & Prob. Chi-Square(2) & 0.8287 \\
\hline
\end{tabular}


Sumber : Data diolah, 2020

Dari data diatas dapat diperoleh nilai Obs*R-squared $(0,8287)>$ nilai tabel chisquare $\left(\mathrm{X}^{2}\right)$ sebesar $\alpha-5 \%(0.05)$ artinya model tidak terdapat autokorelasi.

\section{Uji heteroskedasitas}

Merupakan salah satu asumsi OLS jika variabel residualnya tidak sama. Uji heteroskedastisitas dimaksud untuk menguji varian gangguan (e) tidak mengalami penyebaran yang sama, sehingga model yang sudah dibuat menjadi kurang efisien.

Tabel 6. Heteroskedasitas

Heteroskedasticity Test: Breusch-Pagan-Godfrey

\begin{tabular}{llll}
\hline F-statistic & 0.865441 & Prob. F(3,14) & 0.4820 \\
Obs*R-squared & 2.815913 & Prob. Chi-Square(3) & 0.4209 \\
Scaled explained SS & 1.434998 & Prob. Chi-Square(3) & 0.6974 \\
\hline
\end{tabular}

Sumber : Data diolah, 2020

Dari Tabel 6 nilai chi-square hitung sebesar 0.6974 yang diperoleh dari Obs*Rsquared. Sedangkan nilai tabel prob. chi-square pada model ialah $0.6974>\alpha=5 \%(0,05)$ Karena chi-square hitung lebih besar dari nilai tabel chi-square maka dapat disimpulkan tidak ada masalah heteroskedastisitas.

\section{KESIMPULAN DAN SARAN}

\section{Kesimpulan}

Perkembangan produksi, tenaga kerja, investasi dan unit usaha di Kota Jambi, menunjukkan bahwa tenaga kerja dan investasi sangat mempengaruhi tingkat produksi batik di Kota Jambi. Dengan tenaga kerja yang banyak maka akan meningkatkan jumlah produksi dan Investasi merupakan biaya pengeluaran untuk penanaman modal atau pengeluaran perusahaan untuk membeli barang-barang.

Tenaga kerja berpengaruh positif dan signifikan terhadap produksi batik, peningkatan tenaga kerja akan menghasilkan barang lebih banyak. Investasi berpengaruh negatif dan signifikan terhadap produksi batik Kota Jambi, penambahan investasi dapat menambah kemampuan memproduksi barang dan jasa yang tersedia dalam perekonomian. Investasi berpengaruh negatif dan signifikan terhadap produksi batik Kota Jambi. Faktor produksi adalah input untuk menghasilkan barang dan jasa, secara simultan berpengaruh terhadap produksi. Unit Usaha berpengaruh negatif dan tidak signifikan terhadap produksi batik Jambi. ketika terjadi peningkatan jumlah industri tentu akan menyerap tenaga kerja baru yang lebih besar. Tidak berpengaruhnya secara signifikan karena ketikan seorang pengusaha mendapatkan investasi untuk melakukan ekspansi perusahaan mereka akan menambah kapasitas produksi dengan menambah tenaga kerja baru dan bukan membuka usaha baru.

\section{Saran}

Untuk meningkatkan jumlah produksi batik perlu adanya kebijakan untuk mengadakan pelatihan atau skill dasar sebelum bekerja pada bidang unit usaha dalam memproduksi batik kususnya di Kota Jambi.

Peningkatan jumlah produksi batik di Kota Jambi sangat dipengaruhi oleh keadaan perekonomian, karena kegiatan produksinya tergantung pada keadaan ekonomi, jadi diharapkan pemerintah Kota Jambi dapat menjaga kestabilan perekonomian agar 
terciptanya iklim ekonomi dan investasi yang kondusif sehingga kegiatan perekonomian dapat terus berkembang.

\section{DAFTAR PUSTAKA}

Arsyad, Lincolin.(2010). Ekonomi pembangunan. Edisi Lima. UUP STIMYKPN :Yogyakarta

Badan Pusat Statistik. (2008). Industri, diakses dalam http://bps.go.id, Tanggal 21 Januari 2017, Puku 12.30 WIB

Djoemen, Nian S. (1990). Batik dan mitra: batik and its kinds, Djambatan :Jakarta.

Karib, Abdul. (2012). Analisis pengaruh produksi investasi dan unit usaha terhadap penyerapan tenaga kerja pada sektor industri sumatera Utara.Universitas Andalas: Padang.

Kuncoro, Mudrajad. (2007). Ekonomi pembangunan : Teori, Masalah dan Kebijakan, UPP AMP YKPN:Yogyakarta

Mankiw, Gregory, N. (2003). Pengantar ekonomi edisi kedua jilid satu. Erlangga: Jakarta.

Mulyani. Sri. (2011). Penyerapan tenaga kerja pada industri kecil dan konveksi. Fakultas Ekonomi dan Bisnis.

S Sunargo, D Hastuti. (2019).Mengatasi perilaku kerja kontraproduktif melalui peran integratif politik organisasional dan kecerdasan emosional pada era revolusi industri 4.0, Jurnal Paradigma Ekonomika 14 (2), 45-54

Simanjuntak, Payaman. (2001). Pengantar ekonomi sumber daya manusia . LPFEUI: Jakarta.

Sugiyono. (2014). Metode penelitian pendidikan pendekatan kuantitatif, kualitatif, dan $R \& D$. Alfabeta: Bandung.

Suherman, Ayi. (2002). Penelitian pendidikan. Sumedang : CV. Bintang Warti Artika.

Sukirno, Sadono. (2006). Ekonomi pembangunan: proses, masalah dan kebijakan. Jakarta.

Sukirno, Sadono. (2010). Makro ekonomi: teori pengantar. Rajawali Pers: Jakarta

Sumarsono, Sonny. (2003). Ekonomi manajemen sumberdaya manusia dan ketenagakerjaan. Graha Ilmu:Yogyakarta.

Suparmoko. (2013). Pengantar ekonomi mikro. BPFE: Yogyakarta.

Tambunan, Tulus. (2002). Usaha kecil dan menengah di indonesia: beberapa isu penting. Salemba Empat: Jakarta.

WP Rahayu, PH Prihanto, E Achmad. (2016). Faktor-faktor yang mempengaruhi penyerapan tenaga kerja pada industri batik di Kecamatan Danau Teluk Kota Jambi, e-Jurnal Ekonomi Sumberdaya dan Lingkungan 5 (3) 